\title{
Siamese crocodile bile induces apoptosis in NCI-H1299 human non-small cell lung cancer cells via a mitochondria-mediated intrinsic pathway and inhibits tumorigenesis
}

\author{
LING TIAN $^{1 *}$, YI-TAO DENG $^{1 *}$, XIN DONG $^{1}$, JIA-YI FAN ${ }^{1}$, HUA-LIANG LI ${ }^{1}$, \\ YU-MEI DING ${ }^{1}$, WEI-XI PENG ${ }^{1}$, QING-XI CHEN ${ }^{1}$ and DONG-YAN SHEN ${ }^{2}$ \\ ${ }^{1}$ State Key Laboratory of Cellular Stress Biology, School of Life Sciences, Xiamen University, Xiamen, Fujian 361005; \\ ${ }^{2}$ Center Laboratory, The First Affiliated Hospital of Xiamen University, Xiamen, Fujian 361003, P.R. China
}

Received August 9, 2015; Accepted January 9, 2017

DOI: $10.3892 / \mathrm{mmr} .2017 .6211$

\begin{abstract}
Non-small-cell lung cancer (NSCLC) is a widespread and particularly aggressive form of cancer. Patients with NSCLC and early metastases typically have poor prognosis, highlighting the critical need for additional drugs to improve disease outcome following surgical resection. The present study aimed to determine if Siamese crocodile bile (SCB) had an anti-cancer effect on NCI-H1299 human NSCLC cells. The inhibitory mechanism of SCB was examined in cell culture and nude mice. In vitro experimental results revealed that SCB inhibited the proliferation and colony-forming ability of NCI-H1299 cells by arresting cell cycle and inducing apoptosis. The loss of the mitochondrial membrane potential and the release of cytochrome $c$ indicated that SCB treatment may lead to mitochondrial dysfunction in NCI-H1299 cells. At the molecular level, SCB altered the ratio of protein expression of $\mathrm{Bax} / \mathrm{Bcl}-2$ and activated associated caspases, suggesting that intrinsic pathway involvement in the SCB-induced apoptosis of NCI-H1299 cells. In the in vivo experiments, intraperitoneal injection of SCB for 4 weeks inhibited xenograft tumor
\end{abstract}

Correspondence to: Dr Qing-Xi Chen, State Key Laboratory of Cellular Stress Biology, School of Life Sciences, Xiamen University, 348 Xiang An Nan Road, Xiamen, Fujian 361005, P.R. China E-mail: chenqx@xmu.edu.cn

Dr Dong-Yan Shen, Center Laboratory, The First Affiliated Hospital of Xiamen University, 55 Zhen Hai Road, Xiamen, Fujian 361003, P.R. China

E-mail: shendongyan@163.com

*Contributed equally

Abbreviations: NSCLC, non-small cell lung cancer; SCB, siamese crocodile bile; TEM, transmission electron microscopy; ROS, reactive oxygen species; $\mathrm{IC}_{50}$, half maximal inhibitory concentration

Key words: siamese crocodile bile, NSCLC, apoptotic cell death, intrinsic pathway, xenograft tumor growth by $46.8 \%$ without observable toxicity in nude mice. Immunohistochemistry analysis of proliferating cell nuclear antigen and vascular endothelial growth factor also revealed that SCB inhibited cell proliferation and metastasis in NSCLC xenograft tumors. Overall, SCB exerted an anti-cancer effect on NCI-H1299 human NSCLC cells in vitro and in vivo and may have therapeutic potential for the treatment of human NSCLC.

\section{Introduction}

Worldwide, lung cancer caused the mortality of 1.5 million people in 2010, with an overall 5-year survival of $16 \%$ in the USA and $<10 \%$ in the UK (1). The primary types of lung cancer are small-cell lung cancer (SCLC) and non-small cell lung cancer (NSCLC). The majority of lung cancers $(80 \%)$ are NSCLC (2); of these patients, $>65 \%$ were diagnosed with locally advanced or metastatic disease (3). Therefore, NSCLC is a malignancy with poor prognosis. Despite advances in chemotherapy, further investigation is required to identify novel therapeutic agents to reduce mortality.

Bile is a product of vertebrate liver cells. It contains high levels of bile acids, including chenodeoxycholic acid, ursodeoxycholic acid, cholic acid and deoxycholic acid (4). Bile acids are the main components of bile (50-70\%) and have important physiological functions in organisms. Additionally, bile acids act as a valuable biosurfactant and may form several supramolecular self-assemblies, including micelles and vesicles, which possess potential drug delivery properties.

Animal bile as a natural product has been used as traditional medicine without side effects for thousands of years in China. Since the 1980s, bile and bile acids have received extensive attention in the fields of chemistry and medicine (5). The medicinal value of animal bile, such as bear and snake bile, have been recognized for their immunity enhancing, anti-inflammatory, anti-convulsion and analgesic effects (6). The medicinal value of bile has recently investigated in cancer research fields. It has been determined that animal bile has anti-cancer activity (7).

The crocodile is an ancient vertebrate animal, which has existed for $>200$ million years. Currently, systematic research 
on the crocodile, particularly regarding aspects of medicinal value, has indicated the crocodile may have various unexplored uses. Previous research on the use of Siamese crocodile bile (SCB) has been limited; therefore, the present study aimed to identify its biological activity and particularly the anti-cancer activity of SCB. The Siamese crocodile is a freshwater crocodile primarily located in South East Asia. Siamese crocodile populations have declined greatly due to commercial hunting for the leather industry. The species was granted 'Critically Endangered' status by the International Union for Conservation of Nature Red List in 1996 (8), conservation measures, such as improved habitat management have been put in place in order to stabilize the existing populations. As Siamese crocodile farming is legal and widespread in the south of China any future use of SCB should not affect the wild populations and allow for sustainable sourcing of SCB. Previous studies determined that SCB has an anti-cancer effect against cholangiocarcinoma and hepatocarcinoma cells $(9,10)$. However, the potential use of SCB against human NSCLC cells and the underlying mechanism of its action have not been fully elucidated. Therefore, the present study evaluated the effects of SCB on the apoptosis of NCI-H1299 human NSCLC cells. To the best of our knowledge, this is the first study to demonstrate that SCB inhibited the proliferation of NCI-H1299 human NSCLC cells and induced apoptosis via a mitochondria-mediated intrinsic pathway in vitro. Additionally, it was observed that SCB suppressed the NSCLC xenograft tumorigenesis. These results suggested that $\mathrm{SCB}$ may be a potential therapeutic agent for the treatment of human NSCLC.

\section{Materials and methods}

Reagents.Rhodamine 123(Rh123),3-(4,5-dimethylthiazol-2-yl) 2,5-diphenyl tetrazolium bromide (MTT), z-VAD-fmk and 2', 7'-dichlorofluorescin diacetate (DCF-DA) were purchased from Sigma-Aldrich; Merck Millipore (Darmstadt, Germany). Annexin-fluorescein isothiocyanate (FITC)/propidium iodide (PI) Apoptosis Assay kit and Caspase-3 Activity Apoptosis Assay kit were purchased from KeyGen Biotech Co. Ltd. (Nanjing, China). Cell Mitochondria Isolation kit was purchased from Takara Bio Inc. (Otsu, Japan). RPMI-1640 medium and fetal bovine serum (FBS) were obtained from Gibco; Thermo Fisher Scientific, Inc. (Waltham, MA, USA). The primary antibodies for human B cell leukemia/lymphoma (Bcl-2; cat. no. sc-7382; 1:1,000), Bcl2 associated X (Bax; cat. no. sc-23959; 1:1,000), cytochrome $c$ (cat. no. sc-13156; 1:1,000), apoptotic peptidase activating factor 1 (Apaf-1; cat. no. sc-65890; 1:1,000), survivin, cytochrome $c$ oxidase subunit 4 (COX IV; cat. no. sc-69359; 1:1,000), $\beta$-actin (cat. no. sc-8432; 1:1,000) and proliferating cell nuclear antigen (PCNA; cat. no. sc-56; 1:1,000), vascular endothelial growth factor (VEGF; cat. no. sc-7269; 1:1,000) used for immunohistochemistry (IHC) were purchased from Santa Cruz Biotechnology, Inc. (Dallas, TX, USA). The antibodies for cleaved caspase-3 (cat. no. ab136812; 1:250; Abcam, Cambridge, UK) and -9 (cat. no. 9501; 1:1,000; Cell Signaling Technology, Inc., Danvers, MA, USA), cyclin D1 (cat. no. ab134175; 1:5,000; Abcam), cyclin E1 (cat. no. 4129; 1:1,000; Cell Signaling Technology, Inc.) and cyclin-dependent kinase 2 (Cdk2; cat. no. 2546; 1:1,000;
Cell Signaling Technology, Inc.). Polyvinylidene difluoride (PVDF) membranes obtained from Merck Millipore. Goat anti-rabbit and anti-mouse secondary antibodies conjugated to horse-radish peroxidase (HRP) or FITC were purchased from Tiangen Biotech Co., Ltd. (Beijing, China). Enhanced HRP-DAB Chromogenic Substrate kit and Ultrasensitive SAP kit were purchased from MaiXin Bio (Fuzhou, China). All remaining chemicals were purchased from Sigma-Aldrich.

$S C B$ preparation. Siamese crocodile gallbladders were supplied by Sriracha Tiger Zoo Co., Ltd., (Sriracha, Thailand). The gallbladders were sliced to obtain the fresh bile juice. The bile juice was subsequently centrifuged at $10,000 \mathrm{x} g$ for $30 \mathrm{~min}$ at $4^{\circ} \mathrm{C}$. The supernatant was pooled and vacuum dried into a powder. The SCB powder was stored in aliquots at $4^{\circ} \mathrm{C}$. Concentrations (w/v in medium or normal saline) of SCB were used for the in vitro and in vivo experiments.

Cell culture. NCI-H1299 human NSCLC cells were obtained from the Type Culture Collection of the Chinese Academy of Sciences (Shanghai, China). The cells were cultured in RPMI 1640 supplemented with 10\% FBS, penicillin $(100 \mathrm{U} / \mathrm{ml})$ and streptomycin $(100 \mu \mathrm{g} / \mathrm{ml})$. The cells were incubated at $37^{\circ} \mathrm{C}$ in a humidified atmosphere with $5 \% \mathrm{CO}_{2}$.

Cell viability assay. Cell viability was determined using an MTT assay. Briefly, cells were seeded in 96-well plates at a density of $5.0 \times 10^{3}$ cells/well. Following an overnight culture, the cells were treated with increasing concentrations of SCB $(6.25,12.5,25,50,75$ and $100 \mu \mathrm{g} / \mathrm{ml})$, the same volume medium was used for the control. The treatment was applied for 12, 24 and $48 \mathrm{~h}$. Following treatment, $20 \mu \mathrm{l} \mathrm{MTT}(5 \mathrm{mg} / \mathrm{ml})$ was added to each well and the cells were incubated for another $4 \mathrm{~h}$ at $37^{\circ} \mathrm{C}$. The medium was subsequently removed and $150 \mathrm{ml}$ DMSO was added to each well. The absorbance of each well was recorded at $490 \mathrm{~nm}$ using a microplate spectophotometer. All experiments were repeated at least three times.

Cell colony formation assay. Cells were seeded at densities of 500, 1,000, 2,000 cells in $100 \mathrm{~mm}$ plates and divided into two groups. One group was treated with normal medium as the control and the other group was treated with $40 \mu \mathrm{g} / \mathrm{ml}$ SCB. After 2 weeks, the adherent cell colonies were fixed with methanol for $15 \mathrm{~min}$ at room temperature and then stained with Giemsa at a dilution of 1:10 for $10 \mathrm{~min}$ and washed with PBS three times. Finally, the cell colony numbers were counted.

Cell cycle analysis. NCI-H1299 cells were treated with different concentrations of SCB $(20,40,60 \mu \mathrm{g} / \mathrm{ml})$ for 12,24 and $48 \mathrm{~h}$. Following treatment, cells were harvested and washed with PBS. The cells were centrifuged at $400 \times \mathrm{g}$ for $5 \mathrm{~min}$ at $10^{\circ} \mathrm{C}$ and the supernatant was removed. The pellet was fixed in cold $70 \%$ ethanol on ice for $30 \mathrm{~min}$. The cells were washed twice and centrifuged again at $400 \mathrm{x} g$ for $5 \mathrm{~min}$ at $10^{\circ} \mathrm{C}$. The pellet was re-suspended in binding buffer. Subsequently, the cells were treated with $50 \mu \mathrm{l}$ RNase (stock $100 \mathrm{mg} / \mathrm{ml}$ ) and $200 \mu \mathrm{l}$ PI (stock solution $50 \mu \mathrm{g} / \mathrm{ml}$ ) and incubated at $37^{\circ} \mathrm{C}$ for 30 min without light. The cell cycle stages were immediately analyzed by flow cytometry using FlowJo version 9.0 (Tree 
Star, Inc., Ashland, OR, USA). For each measurement, at least 20,000 cells were counted.

Transmission electron microscopy (TEM). NCI-H1299 cells with and without SCB treatment (20, 40 and $60 \mu \mathrm{g} / \mathrm{ml}$ for $48 \mathrm{~h})$ were fixed with $2.5 \%$ glutaraldehyde in $0.1 \mathrm{M} \mathrm{PBS}(\mathrm{pH} 7.4)$ overnight at $4{ }^{\circ} \mathrm{C}$ and post-fixed in $1 \%$ osmium tetraoxide for 30 min. Following washing with PBS, the cells were progressively dehydrated in a $10 \%$ graded series of $50-100 \%$ ethanol and propylene oxide and embedded in Epon 812 resin. The blocks were cut into ultrathin sections $(5 \mu \mathrm{m})$ using a microtome and the sections were stained with saturated uranyl acetate and lead citrate. The ultrastructure of cells and mitochondria were then observed under a transmission electron microscope (JEM-2100HC; Jeol, Ltd., Tokyo, Japan).

Cell apoptotic assay. NCI-H1299 cells were treated with different concentrations of SCB $(20,40,60 \mu \mathrm{g} / \mathrm{ml})$ for up to $24 \mathrm{~h}$. Following the treatment, the cells were harvested, washed in PBS and re-suspended in $100 \mu \mathrm{l}$ Annexin-binding buffer. The suspension was incubated with $5 \mu \mathrm{l}$ Annexin V-FITC and $10 \mu \mathrm{l}$ PI (working solution in the aforementioned Annexin-FITC/PI Apoptosis Assay kit) for $15 \mathrm{~min}$ at room temperature in the dark. Following staining, $400 \mu$ l Annexin-binding buffer was added and the cells were immediately analyzed by flow cytometry using FlowJo version 9.0. For each measurement, at least 20,000 cells were counted.

Quantification of reactive oxygen species (ROS). DCF-DA is a fluorogenic freely permeable tracer specific for ROS. NCI-H1299 cells were plated in a 6-well plate at a density of $1 \times 10^{6}$ cells/well. The cells were treated with different concentrations of SCB $(20,40,60 \mu \mathrm{g} / \mathrm{ml})$ for 24 and $48 \mathrm{~h}$. Following treatment, the cells were incubated with $10 \mathrm{mM}$ DCF-DA at $37^{\circ} \mathrm{C}$ for $30 \mathrm{~min}$ in the dark. Subsequently, the cells were harvested and washed in PBS. ROS generation was expressed as mean fluorescence intensity, which was detected by flow cytometry using FlowJo version 9.0.

Quantification of mitochondrial membrane potential ( $\Delta \Psi m)$. Rh123 was used to detect changes in the $\Delta \Psi \mathrm{m}$ of NCI-H1299 cells. NCI-H1299 cells were plated in 6-well plates at a density of $2 \times 10^{5}$ cells/well. Following an overnight culture, the cells were treated with $40 \mu \mathrm{g} / \mathrm{ml} \mathrm{SCB}$ for up to $48 \mathrm{~h}$. The cells washed with PBS three times and then stained with Rh123 staining solution at room temperature for $20 \mathrm{~min}$ in the dark and observed under an ordinary inverted phase-contrast microscope (Olympus Corporation, Tokyo, Japan).

The $\Delta \Psi \mathrm{m}$ was quantified by flow cytometry. Following SCB treatment $(20,40,60 \mu \mathrm{g} / \mathrm{ml})$ for $24 \mathrm{~h}$, NCI-H1299 cells were harvested, washed in PBS, and incubated with Rh123 $(1 \mathrm{mg} / \mathrm{ml})$ at $37^{\circ} \mathrm{C}$ in a $5 \% \mathrm{CO}_{2}$ incubator for $20 \mathrm{~min}$. The cells were re-suspended in PBS. Subsequently, the $\Delta \Psi \mathrm{m}$ was analyzed by flow cytometry using FlowJo version 9.0 at an excitation wavelength of $488 \mathrm{~nm}$ and an emission wavelength of $530 \mathrm{~nm}$.

Cytochrome c release assay. Mitochondria were isolated from the cells using the aforementioned Cell Mitochondria Isolation kit according to the manufacturer's protocol. Briefly, the cells were treated with $\mathrm{SCB}(40 \mu \mathrm{g} / \mathrm{ml})$ for different time periods $(0,12,24,48 \mathrm{~h})$, harvested and re-suspended in hypotonic buffer. Following the lysis of cells, mitochondrial fractions were isolated by differential centrifugation: Centrifuged at $700 \times \mathrm{g}$ for $10 \mathrm{~min}$ at $4^{\circ} \mathrm{C}$, the supernatant was collected and centrifuged at $12,000 \times \mathrm{g}$ for $15 \mathrm{~min}$ at $4^{\circ} \mathrm{C}$. Subsequently, the supernatant was removed, the pellet washed and centrifuged at $12,000 \times \mathrm{g}$ for $5 \mathrm{~min}$ at $4^{\circ} \mathrm{C}$. Protein from the cytosolic and mitochondrial fractions of each sample was analyzed by western blotting using an anti-cytochrome $c$ antibody.

Caspase-3 activation assay. A Caspase-3 Colorimetric Assay kit was used according to the manufacturer's protocol to investigate the caspase- 3 activation following SCB treatment. Briefly, NCI-H299 cells were treated with SCB $(20,40,60 \mu \mathrm{g} / \mathrm{ml})$ for up to $48 \mathrm{~h}$. Following the treatment, the cells were harvested and lysed with a RIPA lysis buffer on ice for $1 \mathrm{~h}$. Cells were centrifuged at $10,000 \times \mathrm{x}$ for $1 \mathrm{~min}$ to obtain the lysate. The total protein concentration was determined using the Coomassie brilliant blue method. Enzymatic reactions were performed in a 96-well plate and the same protein quantity of cell lysate was incubated with the substrate for $4 \mathrm{~h}$ at $37^{\circ} \mathrm{C}$. The absorbance was measured at $405 \mathrm{~nm}$.

Western blot analysis. Western blot analysis was performed as previously described (10). Protein $(20 \mu \mathrm{g})$ underwent SDS-PAGE and then transferred onto PVDF membranes. The membranes were blocked by non-fat milk for $1 \mathrm{~h}$ and then incubated with primary and subsequently secondary antibodies. The enhanced chemiluminescence system was used to quantify protein expression.

Xenograft tumor mouse model. All the protocols used were approved by the Xiamen University Laboratory Animal Center (Xiamen, China). A total of 12 female athymic (BALB/c, nu/nu; 6-weeks old, weight, 20 \pm 5 g) nude mice were used in the present study, purchased from Chinese Academy of Sciences, Shanghai Institute for Animals (Shanghai, China). The mice were maintained at $21^{\circ} \mathrm{C}$, humidity $45 \%$ and light/dark cycle of 12 h. NCI-H1299 cells were harvested, washed in PBS, the cells were then counted and suspended in fresh medium. Cells were diluted so that $200 \mu \mathrm{l}$ contained the required number of cells per injection. Around $2 \times 10^{6}$ cells per mouse were injected subcutaneously into the flank of BALB/c nude mice. When the tumor volume reached $\sim 60 \mathrm{~mm}^{3}$, the mice were divided into two groups randomly (6 mice per group). One group received SCB $(100 \mathrm{mg} / \mathrm{kg}$ ) and the other group was used as the control and received normal saline by intraperitoneal injection daily for 5 days/week and $100 \mu \mathrm{l}$ volume for each mouse. The dose of SCB was selected based on our previous study about acute toxicity and chronic toxicity (10). Mice bearing xenograft tumors were monitored every day. The tumor volume was measured once every 4 days using calipers. The tumor volume was estimated according to the following formula: Tumor volume $\left(\mathrm{mm}^{3}\right)=\mathrm{L} \times \mathrm{W}^{2} / 2$; where $\mathrm{L}$ is the length and $\mathrm{W}$ the width. Body weight was recorded once every 4 days; however, it was monitored more frequently during the first 2 weeks in order to identify potential drug-associated toxicity. Following 4 weeks of treatment, the mice were sacrificed 
by $\mathrm{CO}_{2}$ (flow rate, $<2 \mathrm{~L} / \mathrm{min}$ ). The tumors were carefully removed, measured and weighed individually.

Hematoxylin and eosin $(H \& E)$ staining and IHC analysis. Tumors and internal organs (lung and liver) were fixed in formalin and processed for H\&E staining and IHC. The samples were processed as previously described (11). The percentage of PCNA- and VEGF-positive cells was calculated by counting the number of positive-stained cells (crimson or brown color) and the total number of cells in 5 randomly selected fields from each tumor at x400 magnification.

Statistical analysis. Data are presented as the mean \pm standard deviation. SPSS version 13.0 (SPSS, Inc., Chicago, IL, USA) was used for statistical analysis. Student's t test or one-way analysis of variance were used to determine the significant differences between groups. $\mathrm{P}<0.05$ was considered to indicate a statistically significant difference.

\section{Results}

SCB inhibits cell proliferation and colony-forming ability of NCI-H1299 human NSCLC cells. The cytotoxic activity of SCB against human NSCLC NCI-H1299 cells was analyzed by MTT assay in vitro. The cells were treated with indicated concentrations of SCB $(6.25,12.5,25,50,75$ and $100 \mu \mathrm{g} / \mathrm{ml})$ for 12, 24 and $48 \mathrm{~h}$. A clear time-and dose-dependent cytotoxic inhibition was induced by SCB in NCI-H1299 cells (Fig. 1A). Based on the cell inhibitory rates, it was determined that SCB led to complete and prolonged inhibition of NCI-H1299 cells growth up to $48 \mathrm{~h}$, with a decreasing $\mathrm{IC}_{50}$ from 78.25 to $29.02 \mu \mathrm{g} / \mathrm{ml}$ (Fig. 1B).

The effect of SCB on the colony-forming ability of NCI-H1299 cells was also investigated. NCI-H1299 cells are normal cancer cells, which are capable of adherence. An individual adherent cell may grow and develop into a single colony on the plastic surface of tissue culture dish. In the present assay, different quantities of cells $(500,1,000$ and 2,000) were seeded on $10 \mathrm{~cm}$ dishes and divided into two groups. The experimental group was treated with $40 \mu \mathrm{g} / \mathrm{ml} \mathrm{SCB}$ for 2 weeks. The control group was treated with normal medium. Based on the colony numbers that were counted, the colony-forming efficiency of the experimental group was significantly reduced compared with the control group $(\mathrm{P}<0.01$; Fig. $1 \mathrm{C}$ and $\mathrm{D})$.

SCB caused cell cycle arrest and induced apoptotic cell death in NCI-H1299 cells. In order to determine whether the inhibition of proliferation by SCB in NCI-H1299 cells was associated with cell cycle arrest, cells were treated with different concentrations of SCB $(20,40,60 \mu \mathrm{g} / \mathrm{ml})$ for $48 \mathrm{~h}$. DNA content was detected by PI and cell cycle distribution was analyzed by flow cytometry. The flow cytometry results revealed that SCB may regulate the G1 phase and arrest cell cycle at the G0/G1 phase in NCI-H1299 cells (Fig. 2A). Additionally, with increasing concentrations of SCB, the cell population increased at G0/G1 phase (almost 99\% for $60 \mu \mathrm{g} / \mathrm{ml} \mathrm{SCB}$ ) and decreased at $\mathrm{S}$ and G2/M phase accordingly (Fig. 2B). In order to identify the underlying mechanism of SCB regulation of cell cycle progression in NCI-H1299 cells, the protein expression levels of three cell cycle-associated proteins that have been previously identified as rate limiting for $\mathrm{G} 0 / \mathrm{G} 1$ to $\mathrm{S}$ phase transition were investigated (12). Western blotting revealed that the expression levels of cyclin E1 and Cdk2 were reduced in NCI-H1299 cells after treatment $(60 \mu \mathrm{g} / \mathrm{ml}$ for $48 \mathrm{~h})$, whereas the expression of cyclin D1 remained unchanged (Fig. 2C). Therefore, these findings confirmed that SCB may arrest the cell cycle at G0/G1 phase and suppress cellular proliferation.

Apoptosis is the process of programmed cell death that may occur in multicellular organisms (13); cells undergo apoptosis, the morphology changes. Two different samples were prepared (control and $40 \mu \mathrm{g} / \mathrm{ml} \mathrm{SCB}$ treated for $48 \mathrm{~h}$ ) and the morphological characteristics of the cells in the samples were examined by TEM and the ultrastructure of NCI-H1299 cells was clearly observed. Normal cell morphology was evident in the control sample, with an integrated cell nucleus and nuclear envelope. The nucleus was hypertrophied and chromatin was diffuse. However, in the SCB-treated sample, the typical apoptotic morphology was observed, with cell body and nucleus shrinkage, condensed chromatin that was separated and moved to the inside edge of nuclear envelope; however, the nuclear membrane, plasma membrane and organelles were intact (Fig. 2D, red arrows). Subsequently, FITC-conjugated Annexin V and PI were used to distinguish apoptotic and necrotic cells using flow cytometry. With increased duration of SCB treatment, the cell population of early and late apoptotic cells increased compared with the control treatment $(19.38 \%$ for $40 \mu \mathrm{g} / \mathrm{ml} 24 \mathrm{~h}$ ); however, the necrotic cells also increased at higher concentrations of SCB (Fig. 2E). Therefore, it was demonstrated that SCB may induce apoptotic cell death in NCI-H1299 cells.

SCB caused mitochondrial dysfunction in NCI-H1299 cells. ROS are implicated in the mediation of apoptotic cell death (14). In order to investigate whether SCB-induced apoptosis of NCI-H1299 cells may be associated with ROS generation, the intracellular ROS level was examined by flow cytometry. ROS level of SCB-treated cells was increased compared with the control in a time- and dose-dependent manner (Fig. 3A; black arrows). These findings demonstrated that SCB enhanced the intracellular ROS level in NCI-H1299 cells. Mitochondria are the primary site of ROS production; therefore, they are uniquely vulnerable to oxidative damage (15). Oxidative damage stimulates and leads to mitochondrial dysfunction (16). The ultrastructure of mitochondria in NCI-H1299 cells was observed by TEM. Without SCB treatment, the morphology of the mitochondria was normal, with a double membrane and distinct cristae structure, which expands the inner mitochondrial membrane. Following SCB treatment, the mitochondria were damaged, with the organelle swollen and the cristae partially fractured (Fig. 3B; red arrows).

Mitochondrial dysfunction is frequently accompanied by alteration of $\Delta \Psi \mathrm{m}$. Therefore, a reporter dye for mitochondria was used to detect the $\Delta \Psi_{\mathrm{m}}$ in NCI-H1299 cells. Rh123 is a reporter dye for mitochondria of living cells. The yellow-green fluorescence intensity under the microscope reflected the $\Delta \Psi \mathrm{m}$ level of mitochondria (white arrows). As presented in Fig. 3C, SCB led to a marked reduction in fluorescence intensity in NCI-H1299 cells, indicating a reduction of highly energized mitochondria. The effect of SCB on the $\Delta \Psi_{\mathrm{m}}$ in NCI-H1299 cells was also examined by flow cytometry. The 

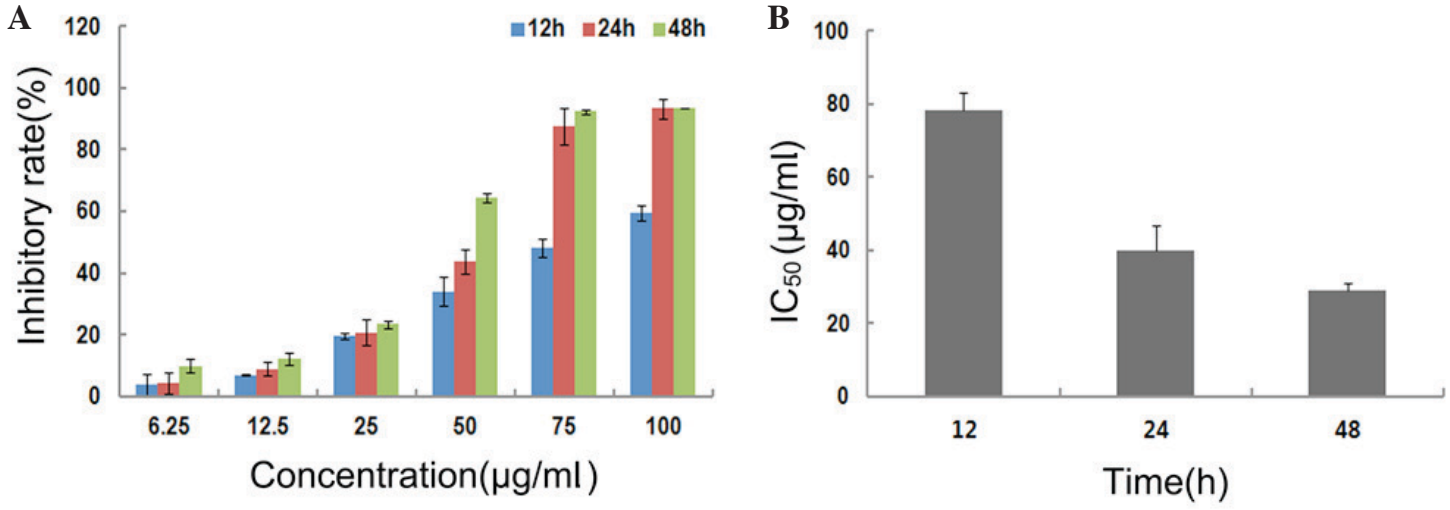

C

D
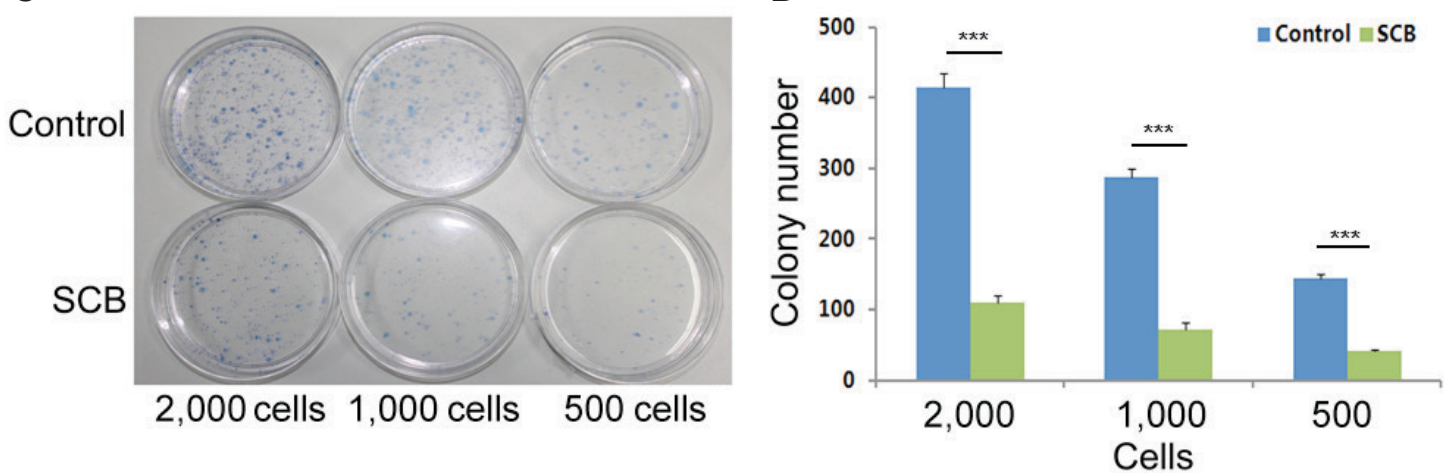

Figure 1. SCB inhibits cell proliferation and colony-forming ability of NCI-H1299 cells. (A) Cell proliferation was determined by methyl thiazolyl tetrazolium assay following treatment with different concentrations of SCB for various time periods. (B) $\mathrm{IC}_{50}$ of SCB on NCI-H1299 cells following different treatment periods. (C) Colony-forming ability assay was performed on NCI-H1299 cells following treatment with $40 \mu \mathrm{g} / \mathrm{ml} \mathrm{SCB}$. Culture dishes were seeded with density of 500, 1,000 and 2,000 NCI-H1299 cells. The formed colonies were stained using Giemsa. (D) Number of colonies in each dish for the control and SCB treatment group was calculated. ${ }^{* * *} \mathrm{P}<0.001$ vs. the control group. SCB, Siamese crocodile bile; $\mathrm{IC}_{50}$, half maximal inhibitory concentration.

result revealed that with the increased dose of SCB (48 h) there was a fluorescence peak (black arrows), which may indicate a collapse of $\Delta \Psi \mathrm{m}$ in NCI-H1299 cells in a dose-dependent manner (Fig. 3D).

SCB induces apoptosis in NCI-H1299 cells via an intrinsic pathway. The present study aimed to assess whether SCB-induced apoptotic cell death occurred due to an intrinsic pathway; therefore, the effects of SCB on intrinsic pathway-associated factors were examined. The expression of Bax and Bcl-2 following SCB treatment $(40 \mu \mathrm{g} / \mathrm{ml})$ was determined at different time points. Western blotting revealed that SCB treatment increased the ratio of $\mathrm{Bax} / \mathrm{Bcl}-2$ at the protein expression level (Fig. 4A). The release of cytochrome $c$ may induce the activation of caspases and lead to apoptotic cell death (17). Therefore, cytochrome $c$ expression level in NCI-H1299 cells was examined by western blotting. Following SCB treatment, cytochrome $c$ expression level increased in the cytosol and decreased in mitochondria in a time-dependent manner (Fig. 4B).

In order to determine whether caspase- 3 was activated during SCB treatment, the caspase-3 activity was examined using a Caspase-3 Activity Assay kit. As presented in Fig. 4C, caspase-3 activity was increased in a dose-dependent manner. There was a significant increase in caspase- 3 activity in the groups treated with 40 and $60 \mu \mathrm{g} / \mathrm{ml}$ SCB when compared with the control $(\mathrm{P}<0.01$ and $\mathrm{P}<0.001$, respectively). Additionally, the cells were treated with PBS only (control), SCB
(40 $\mu \mathrm{g} / \mathrm{ml})$ only, and SCB $(40 \mu \mathrm{g} / \mathrm{ml})$ added pan-caspase inhibitor z-VAD-fmk $(20 \mu \mathrm{M})$ together for $24 \mathrm{~h}$. Additionally, the pan-caspase inhibitor z-VAD-fmk $(20 \mu \mathrm{M})$ significantly reduced $\mathrm{SCB}$-induced cell apoptosis compared with the SCB only treatment $(\mathrm{P}<0.01$; Fig. 4D). Therefore, the present study aimed to determine the association of SCB-induced caspase-3 activation with the increased $\mathrm{Bax} / \mathrm{Bcl}-2$ ratio in intrinsic pathway. The effect of SCB on the expression levels of Apaf-1, cleaved caspase-9 and -3, and survivin were examined (Fig. 4E). Western blotting results revealed that the expression of Apaf-1 was increased in NCI-H1299 cells treated with SCB. The procaspase- 9 and procaspase- 3 were cleaved, the expression of cleaved caspase- 9 and cleaved caspase- 3 also increased with SCB treatment. The expression level of survivin was decreased by SCB treatment in NCI-H1299 cells compared with the control treatment. Therefore, these findings revealed that SCB may induce apoptosis in NCI-H1299 cells through the intrinsic pathway with increased $\mathrm{Bax} / \mathrm{Bcl}-2$ ratio and release of cytochrome $c$.

$S C B$ inhibits the growth of NSCLC xenograft tumors in athymic nude mice without observable toxicity. To verify the in vitro findings, in vivo experiments were performed. The efficacy of SCB against NSCLC xenograft tumors in nude mice was investigated. The present study used SCB powder mixed with normal saline at a dose of SCB $100 \mathrm{mg} / \mathrm{kg}$ in $100 \mu \mathrm{l} / \mathrm{mouse}$ and was administered via intraperitoneal injection (control with normal saline only). After 4 weeks, 
A

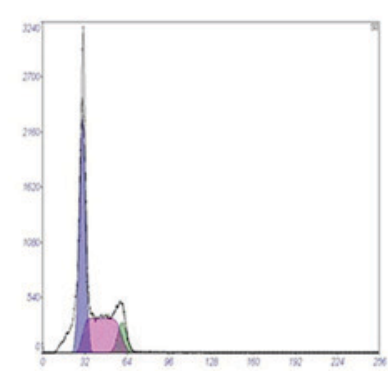

Control

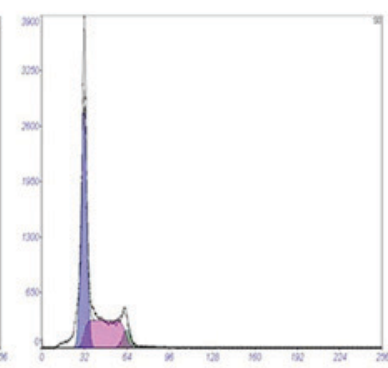

$20 \mu \mathrm{g} / \mathrm{ml}$

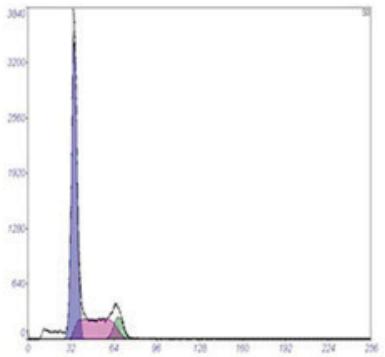

$40 \mu \mathrm{g} / \mathrm{ml}$

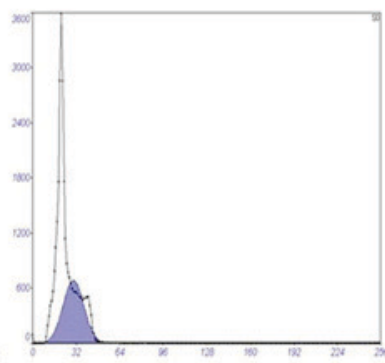

$60 \mu \mathrm{g} / \mathrm{ml}$
B

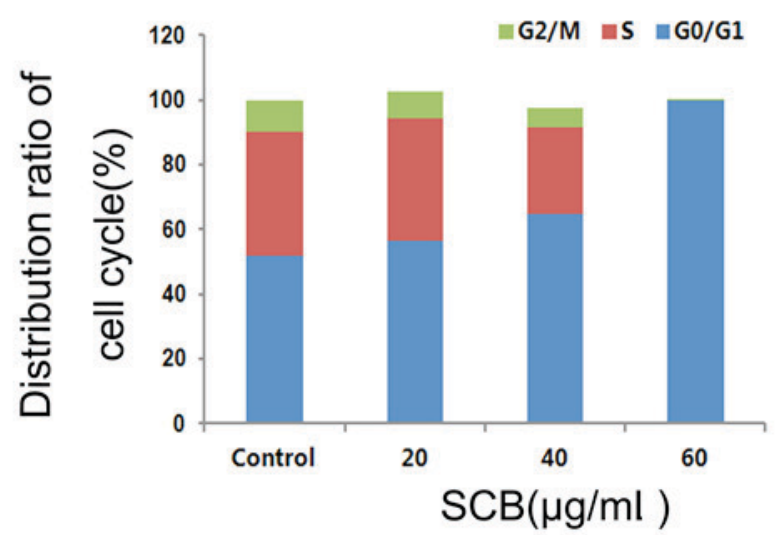

C

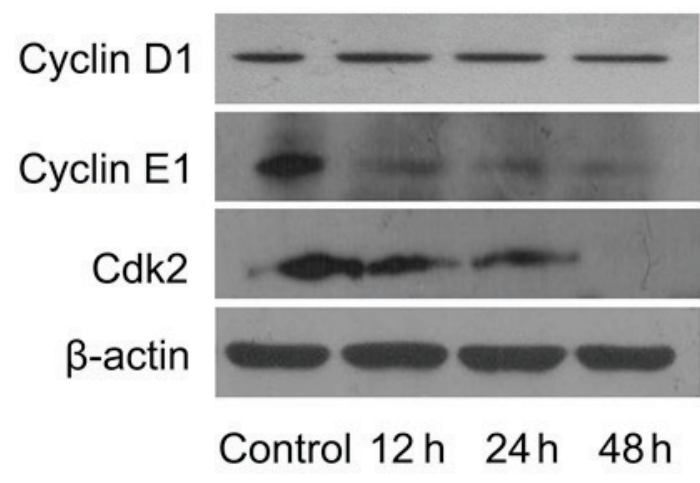

D

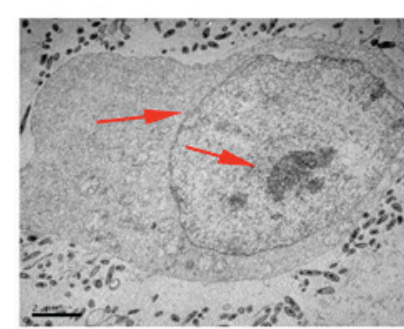

Control

E

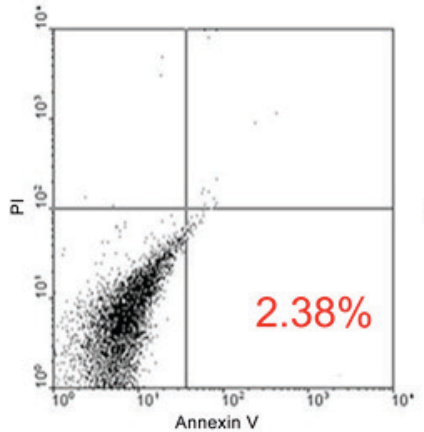

Control
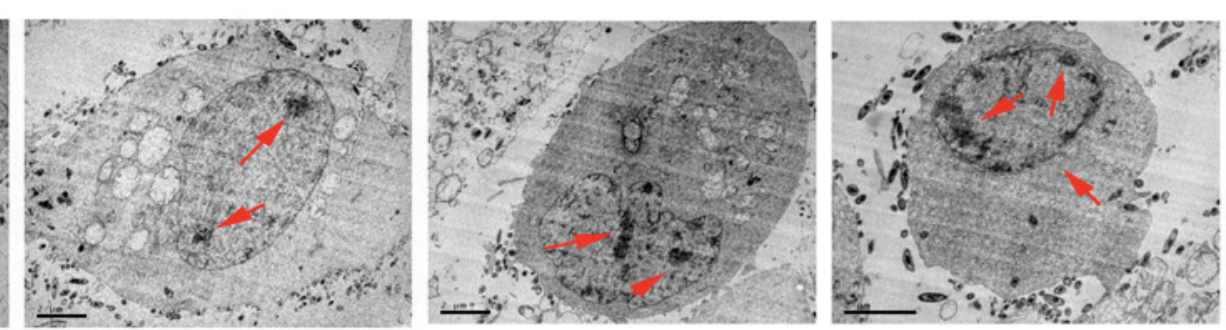

\section{SCB-treated}

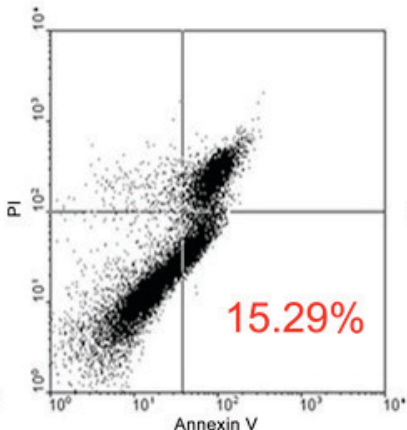

$20 \mu \mathrm{g} / \mathrm{ml}$

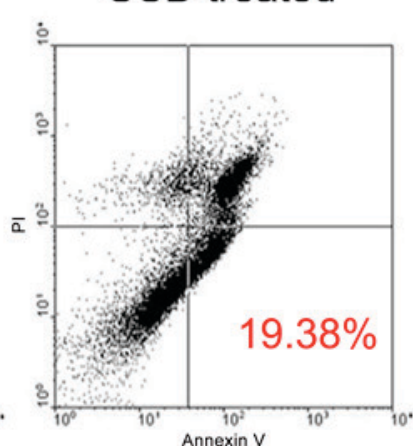

$40 \mu \mathrm{g} / \mathrm{ml}$

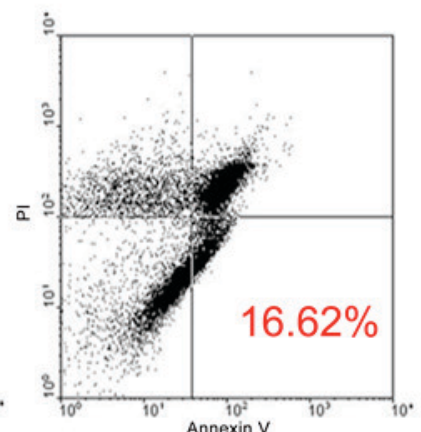

$60 \mu \mathrm{g} / \mathrm{ml}$

Figure 2. SCB induces cell-cycle arrest and apoptotic cell death in NCI-H1299 cells. (A) NCI-H1299 cells cell cycle distribution was analyzed by flow cytometry. (B) Quantification of cell cycle distribution. (C) Cell cycle associated proteins, Cyclin D1, Cyclin E1 and Cdk2, were detected by western blotting. $\beta$-actin was used as internal control. (D) Ultrastructure of NCI-H1299 cells after SCB treatment observed by transmission electron microscopy. The intracellular ultrastructure exhibited apoptotic characteristics (red arrows). Scale bar, $2 \mu \mathrm{m}$. (E) Apoptotic rate in NCI-H1299 cells was assessed by Annexin V-fluorescein isothiocyanate/PI double staining. Quadrant 1 represents live cells, quadrant 2 represents early apoptotic cells, quadrant 3 represents late apoptotic cells and quadrant 4 represents necrotic cell. Representative FACS profiles reveal increasing percentage in early apoptotic cells following SCB treatment for $24 \mathrm{~h}$. SCB, Siamese crocodile bile; Cdk2, cyclin-dependent kinase 2; PI, propidium iodide.

the nude mice were sacrificed and the tumors were collected (Fig. 5A and B). During the experiment mice were observed for general signs of toxicity, such as body weight profile, and the tumor volume was also measured every 4 days
(Fig. 5). These findings indicated that SCB administration at the aforementioned dose did not lead to any body weight loss, which indicated that SCB was well-tolerated by mice at this dose (Fig. 5C). SCB treatment led to a significant 
A
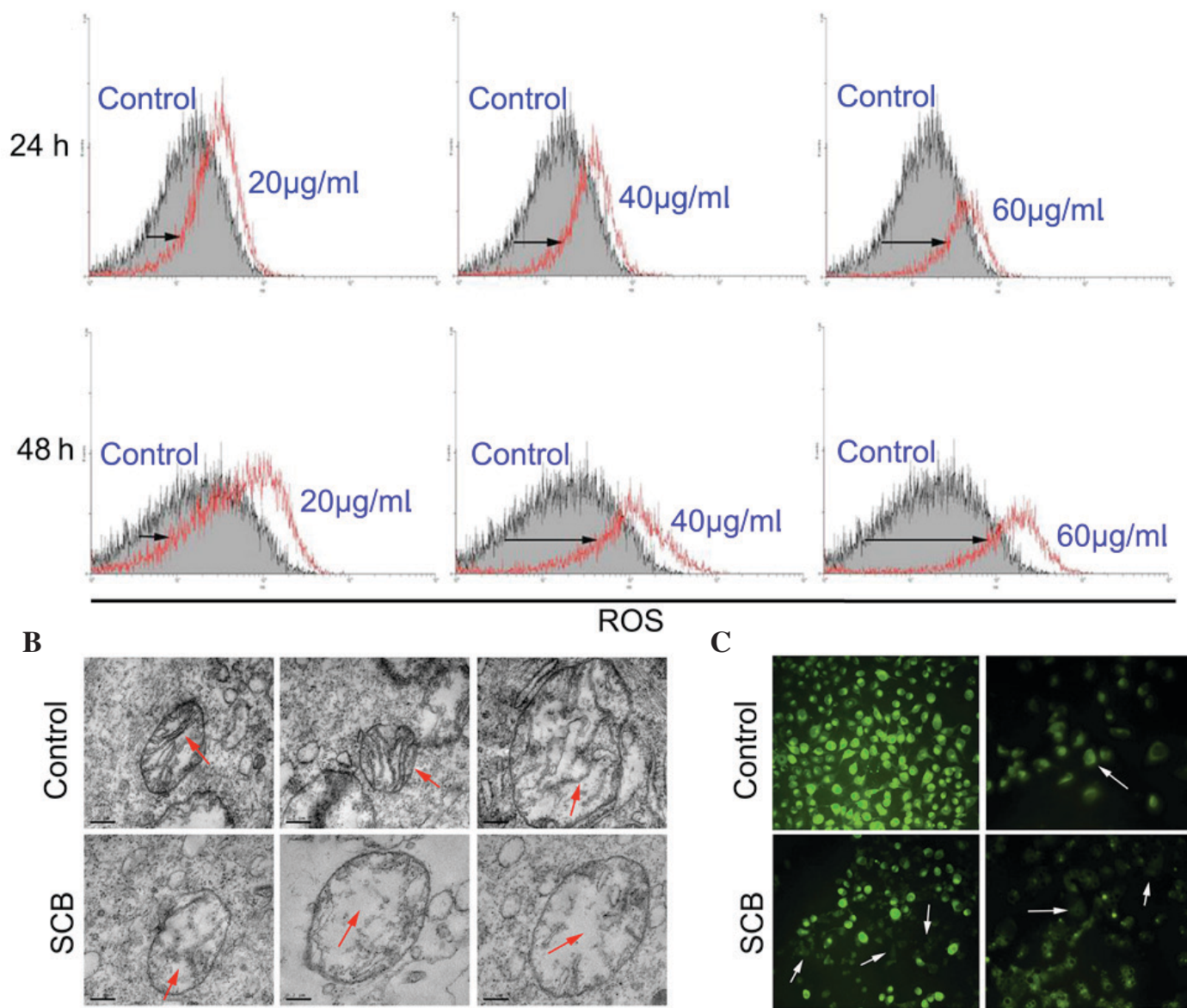

C

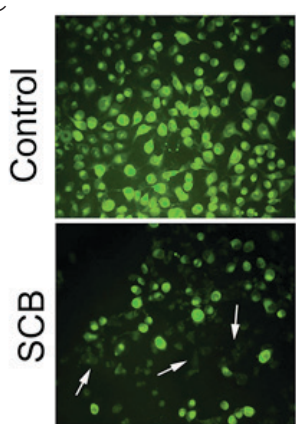

$(\times 200)$

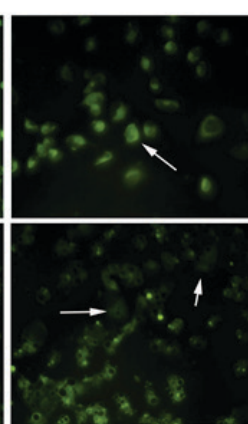

$(\times 400)$

D

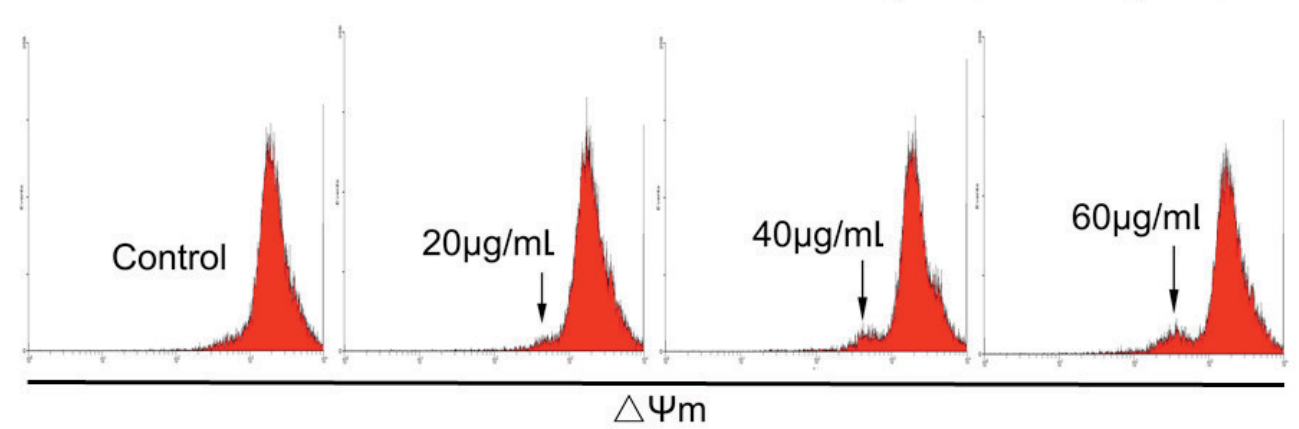

Figure 3. SCB causes mitochondrial dysfunction in NCI-H1299 cells. (A) Flow cytometry analysis of ROS levels in NCI-H1299 cells. (B) Ultrastructure of mitochondria in NCI-H1299 cells following SCB treatment was observed by transmission electron microscopy. The red arrows indicated that the cristae of treated mitochondria were partially fractured. Scale bar, $2 \mu \mathrm{m}$ (C) Effect of SCB on the $\Delta \Psi \mathrm{m}$ level in NCI-H1299 cells. Following staining with Rh123, the yellow-green fluorescent intensity was observed under the inverted fluorescence microscope (white arrows). (D) Effect of SCB on the $\Delta \Psi \mathrm{m}$ in NCI-H1299 cells was analyzed by flow cytometry. The increase of hypofluorescence (indicated by arrows) indicates a loss of $\Delta \Psi \mathrm{m}$. ROS, reactive oxygen species; SCB, Siamese crocodile bile; $\Delta \Psi \mathrm{m}$, mitochondrial membrane potential.

reduction in NSCLC xenograft tumor volume with time (Fig. 5D). The tumor weight was significantly reduced the SCB-treated group $(797.2 \pm 500.54 \mathrm{mg})$ was compared with the control group $(1498 \pm 506 \mathrm{mg})$, with inhibition of $46.8 \%$ $(\mathrm{P}<0.05$; Fig. 5E). The tumor cell morphology was also observed under a microscope by H\&E staining. The tumor section from control group revealed that the nuclei were split and the cells were undergoing mitosis. By contrast, the enhanced basophilic staining of chromatin in the tumor sections from SCB-treated group indicated that the cells were undergoing apoptosis and proliferation was inhibited
(Fig. 5F, yellow arrows in left lower corners). Additionally, the H\&E staining of the liver and lung sections revealed no adverse effects of SCB on these organs (Fig. 5G). In order to confirm the cell proliferation and metastasis in the xenograft tumor from control and SCB-treated groups, IHC of PCNA and VEGF was performed. The number of cells positively-stained for PCNA and VEGF was significantly reduced in the SCB-treated mice compared with the control group $(\mathrm{P}<0.001$; Fig. 5H). Together, these findings suggested SCB treatment has in vivo against NSCLC xenograft growth, without any evident side effects. 
A

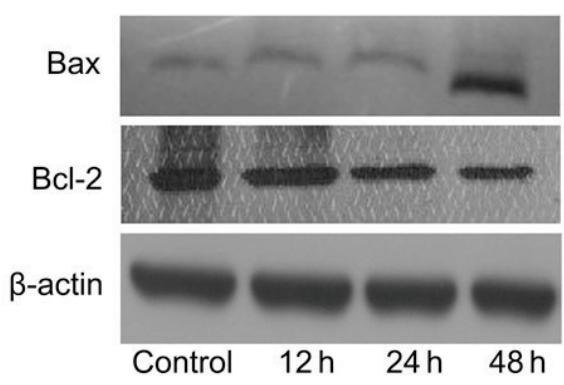

B
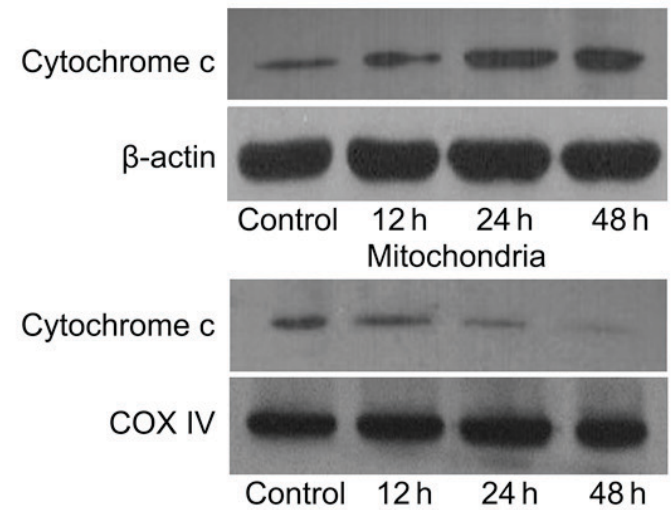

C

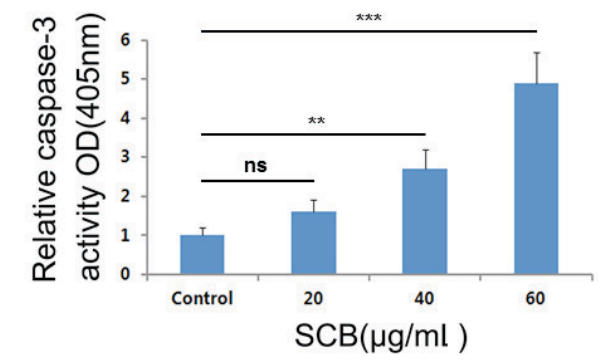

D
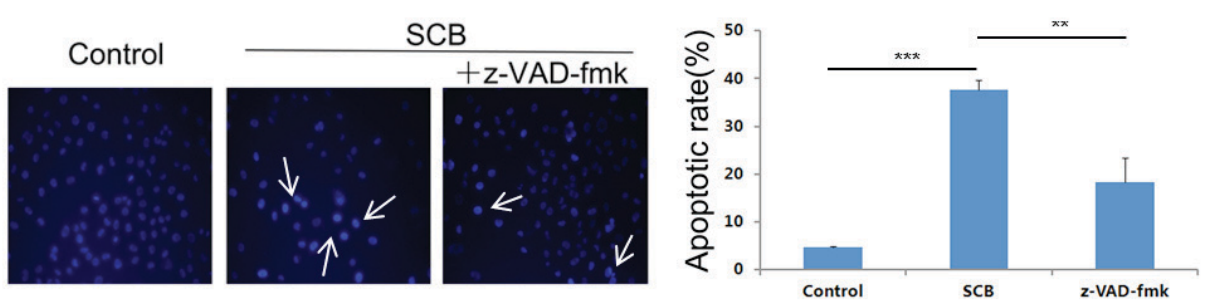

$\mathbf{E}$

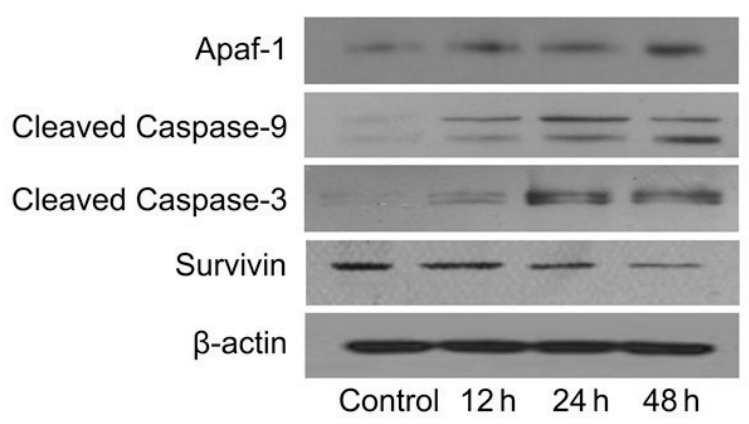

Figure 4. SCB induces apoptotic cell death in NCI-H1299 cells through the intrinsic pathway. (A) Expression of Bax and Bcl-2 following SCB treatment was detected by western blotting. $\beta$-actin was used as an internal control. (B) Cytosolic and mitochondrial fractions were prepared and the level of cytochrome $c$ in cytosol and mitochondria were detected by western blotting. $\beta$-actin and COX IV were used as internal controls. (C) Effect of SCB on the activity of pro/cleaved caspase-3. ${ }^{* * *} \mathrm{P}<0.01,{ }^{* * * *} \mathrm{P}<0.001$ vs. control group. (D) Morphology changes occurred in NCI-H1299 cells following SCB treatment. To inhibit apoptosis, $20 \mu \mathrm{M}$ z-VAD-fmk (a pan-capase inhibitor) was used during SCB treatment. Hoechst 33258 was used to assess cell apoptosis (white arrows). ${ }^{* *} \mathrm{P}<0.01,{ }^{* * *} \mathrm{P}<0.001$ vs. SCB group. (E) Expression of Apaf-1, cleaved caspase-9, cleaved caspase-3 and survivin following SCB treatment were detected by western blotting. $\beta$-actin was used as internal control. Bcl-2, B cell leukemia/lymphoma 2; Bax, Bcl-2 associated X; COX IV, cytochrome $c$ oxidase subunit 4; OD, optical density; SCB, Siamese crocodile bile; Apaf-1, apoptotic peptidase activating factor 1.

\section{Discussion}

NSCLC is any type of epithelial lung cancer other than SCLC. The majority of patients with NSCLC are relatively insensitive to chemotherapy, compared to patients with SCLC (18). Patients with NSCLC are primarily treated by surgical resection, and subsequently chemotherapeutic drugs with curative intent are required. Our previous study determined that SCB has an anti-cancerous effect on several forms of human cancer cell lines by inducing apoptosis $(9,10)$, including human NSCLC .
The present study aimed to investigate the mechanism of SCB-induced apoptosis on NCI-H1299 human NSCLC cells in vitro and its anti-tumor efficacy in vivo.

The present study demonstrated that SCB treatment significantly inhibited the proliferation of NCI-H1299 cells in a time- and dose-dependent manner and their colony-forming ability. Control of cell cycle progression in cancer cells is considered to be an effective method to inhibit tumor growth (19). The findings of the present study revealed that SCB treatment arrested the cell cycle at G0/G1 
A

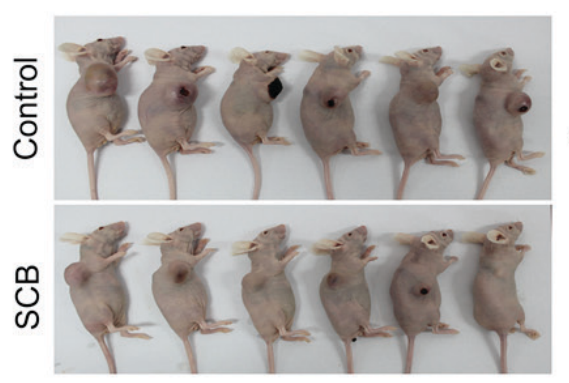

C

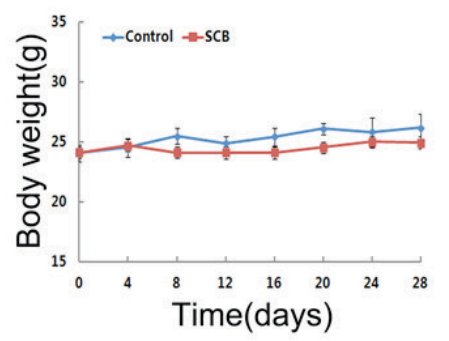

$\mathbf{F}$

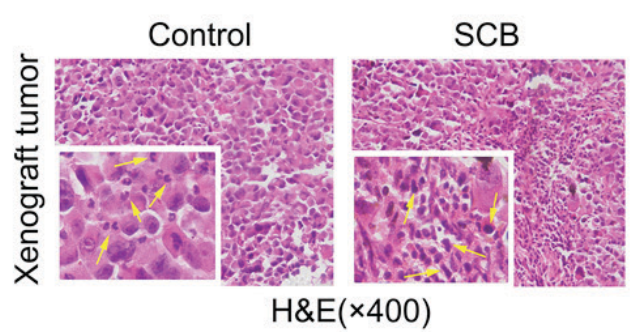

H

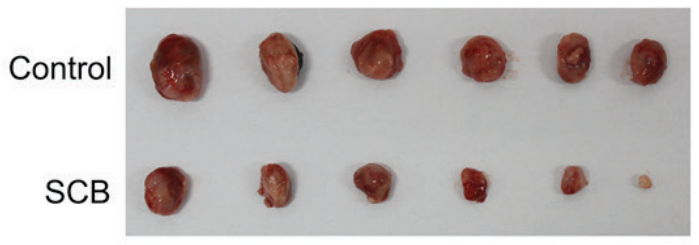

E

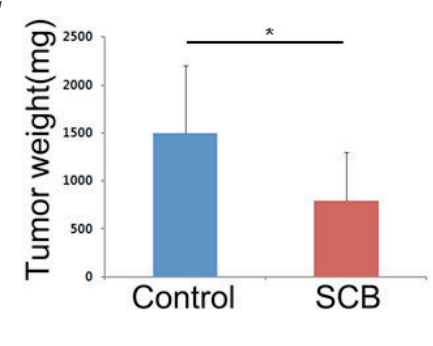

G Control

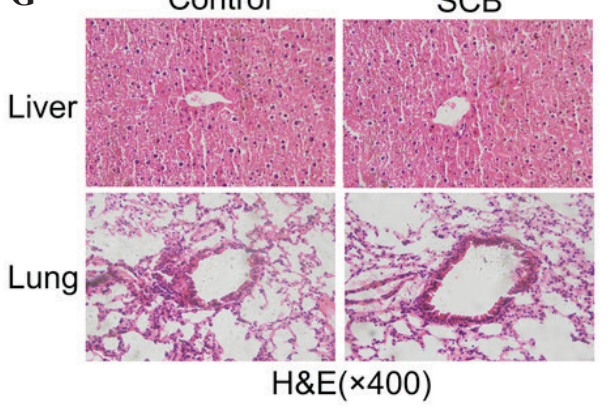

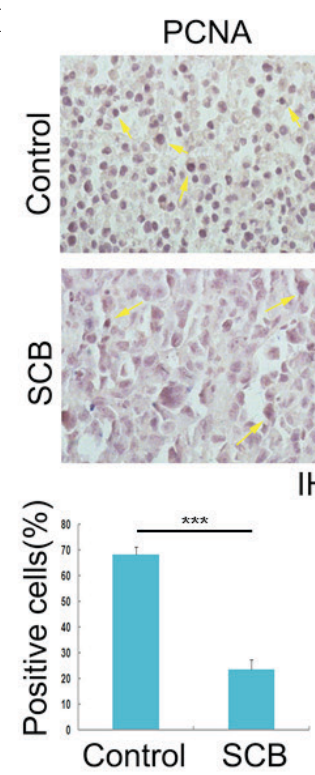

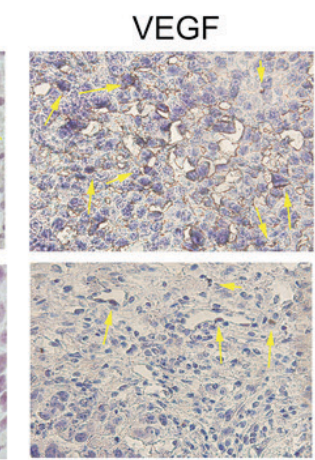

$\mathrm{IHC}(\times 400)$

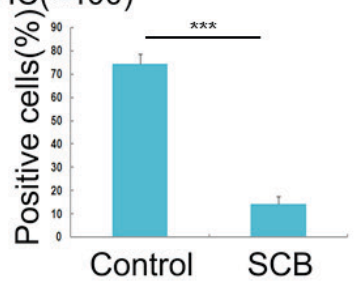

Figure 5. SCB inhibited the growth of NSCLC xenograft tumor in athymic nude mice. (A) Nude mice with solid tumors. Control group was treated with normal saline only. SCB group was treated with SCB. (B) Solid tumors from each group collected after the mice were sacrificed. (C) Body weight variation curve. (D) Tumor volume over time. ${ }^{*} \mathrm{P}<0.05,{ }^{* *} \mathrm{P}<0.01,{ }^{* * *} \mathrm{P}<0.001$ vs. the control group. The body weight and tumor volume was measured every 4 days. (E) Average tumor weight for each group. ${ }^{*}<0.05$ vs. the control group. (F) H\&E analysis of tumor section from control and SCB-treated mice. Yellow arrows indicate the different nucleus morphology. (G) H\&E analysis of liver and lung section from control and SCB-treated mice. (H) IHC analysis was used for PCNA and VEGF in the tumor section from control and SCB-treated mice. Yellow arrows indicate the positive cells. ${ }^{* * *} \mathrm{P}<0.001$ vs. the control group. SCB, Siamese crocodile bile; H\&E, hematoxylin and eosin; PCNA, proliferating cell nuclear antigen; VEGF, vascular endothelial growth factor; IHC, immunohistochemistry.

phase and blocked entry into S phase in NCI-H1299 cells by reduction of the expression of cyclin $\mathrm{E} 1$ and Cdk2, which are required for the G1/S transition (20). These findings suggested that cell cycle regulation contributed to the anti-proliferative effect of SCB treatment in NCI-H1299 cells.

Apoptosis in response to chemotherapeutic drugs is one of the common mechanisms in cancer cell death (21). The present 
study investigated whether the inducing apoptotic cell death following SCB treatment was responsible for inhibition of the growth of NCI-H1299 cells. Changes in cell morphology are primary indicators of apoptosis $(22,23)$, involving cell shrinkage, nuclei chromatin condensation and the formation of apoptotic bodies (23), which were observed in SCB-treated NCI-H1299 cells under TEM. Additionally, the proportion of apoptotic NCI-H1299 cells increased with prolonged SCB treatment. The findings of the present study demonstrated that SCB treatment inhibited the growth of NCI-H1299 cells by inducing apoptotic cell death.

ROS form as a byproduct of oxygen metabolism (24). Excess ROS induces oxidative stress, which functions as a trigger for signaling molecules to initiate downstream events in apoptosis (14). Following exposure of SCB, the intracellular ROS level increased in NCI-H1299 cells. Mitochondria serve a crucial role in the apoptotic process by integrating numerous apoptotic signals from the intracellular space (25). Therefore, the present study focused on the mitochondria in NCI-H1299 cells. The images of mitochondria obtained from TEM revealed that the cristae of the mitochondria were gradually degraded. The regular function of the cristae is to expand the surface area of the inner mitochondrial membrane, enhancing and thus increase the production of ATP via the electron transport chain (25). The yellow-green fluorescent intensity observed under the inverted fluorescence microscope in the present study indicated that the electron transport chain was interrupted and the ATP level was reduced. Therefore, it was concluded that mitochondrial dysfunction occurred following SCB treatment of NCI-H1299 cells. The mitochondria are essential to multicellular life. Once they suffer damage, apoptosis-associated proteins target the mitochondria and increase the permeability of the mitochondrial membrane which causes apoptotic effectors to leak out (26). Therefore, the $\Delta \Psi \mathrm{m}$ was further investigated and the release of cytochrome $c$ following SCB treatment was quantified. The findings revealed that the $\Delta \Psi \mathrm{m}$ was collapsed and cytochrome $c$ was released into the cytoplasm from the mitochondria of NCI-H1299 cells. These events are very closely associated to intrinsic pathway, which arises more frequently in tumors (27). The release of cytochrome $c$ and the activation of caspases are usually under the control of the Bcl-2 family proteins through the intrinsic pathway (28). The Bcl-2 family are involved in the formation of pores on the mitochondrial membrane $(29,30)$. The family consists of the pore-stabilizing protein Bax, as well as the anti-apoptotic pore-destabilizing protein, Bcl-2 (31). The present study determined that the SCB treatment increased the ratio of Bax/Bcl-2 and caspase-3 activity in NCI-H1299 cells. Therefore, it is possible that SCB induced apoptosis in NCI-H1299 cells through this intrinsic pathway. In the intrinsic pathway, once cytochrome $c$ is released it binds with Apaf-1 to produce a protein complex termed the apoptosome (32). The apoptosome possesses a caspase recruitment domain, which allows it to bind and process the crucial initiator, caspase-9 (33). Activated caspase-9 then cleaves and activates the downstream effector, caspase-3, finally initiating specific caspase cascades to induce apoptosis (34). The western blotting findings of the present study indicated that SCB treatment promoted the expression of Apaf-1 and then activated caspase -9 and -3 . Conversely, SCB treatment reduced the expression of survivin. Survivin is a member of the inhibitor of apoptosis family, which functions to inhibit caspase activation, thereby negatively regulating apoptosis (35). Therefore, it is possible that SCB treatment induces apoptosis in NCI-H1299 cells apoptotic via a mitochondria-mediated intrinsic pathway.

Finally, the in vivo animal experimental findings suggested that SCB may inhibit tumor growth in a xenograft model. The tumors in nude mice that received SCB treatment alone were $\sim 46.8 \%$ smaller than the control group. Changes in body weight change were monitored and any changes in liver and lung tissues were assessed using H\&E staining. No toxicity was observed in the nude mice following SCB treatment. IHC analysis revealed that the number of PCNA and VEGF-positive cells were markedly reduced in the xenograft tumors from SCB-treated group compared with the control group. These in vivo findings confirmed the previous results in cell culture.

In conclusion, to the best of our knowledge, the present study demonstrated for the first time, that the inhibitory mechanism of SCB on NCI-H1299 human NSCLC cells in vitro and therapeutic efficacy against xenograft tumors in vivo. These findings support the use of SCB in future clinical studies of human NSCLC.

\section{Acknowledgements}

The present study was supported by the Science and Technology Foundation of the City of Xiamen (grant no. 3502Z20133009), the Natural Science Foundation of China (grant no. 81101502) and the National Science Foundation for Fostering Talents in Basic Research of the National Natural Science Foundation of China (grant no. J1310027).

\section{References}

1. National Lung Screening Trial Research Team, Church TR, Black WC, Aberle DR, Berg CD, Clingan KL, Duan F, Fagerstrom RM, Gareen IF, Gierada DS, et al: Results of initial low-dose computed tomographic screening for lung cancer. N Engl J Med 368: 1980-1991, 2013.

2. Devesa SS, Bray F, Vizcaino AP and Parkin DM: International lung cancer trends by histologic type: Male:female differences diminishing and adenocarcinoma rates rising. Int J Cancer 117: 294-299, 2005.

3. Morgensztern D, Ng SH, Gao F and Govindan R: Trends in stage distribution for patients with non-small cell lung cancer: A National Cancer Database survey. J Thorac Oncol 5: 29-33, 2010.

4. Tint GS, Dayal B, Batta AK, Shefer S, Joanen T, McNease L and Salenet G: Biliary bile acids, bile alcohols, and sterols of Alligator mississippiensis. J Lipid Res 21: 110-117, 1980.

5. Hofmann AF and Roda A: Physicochemical properties of bile acids and their relationship to biological properties: An overview of the problem. J Lipid Res 25: 1477-1489, 1984.

6. Yeh YH, Wang DY, Liau MY, Wu ML, Deng JF, Noguchi T and Hwang DF: Bile acid composition in snake bile juice and toxicity of snake bile acids to rats. Comp Biochem Physiol C Toxicol Pharmacol 136: 277-284, 2003.

7. Feng Y, Siu K, Wang N, Ng KM, Tsao SW, Nagamatsu T and Tong Y: Bear bile: Dilemma of traditional medicinal use and animal protection. J Ethnobiol Ethnomed 5: 2, 2009.

8. Baillie $\mathbf{J}$ and Groombridge B: IUCN red list of threatened animals. The IUCN Species Survival Commission, Gland, Switzerland. 1996.

9. Kang JH, Zhang WQ, Song W, Shen DY, Li SS, Tian L, Shi Y, Liang G, Xiong YX and Chen QX: Apoptosis mechanism of human cholangiocarcinoma cells induced by bile extract from crocodile. Appl Biochem Biotechnol 166: 942-951, 2012. 
10. Song W, Li SS, Qiu PP, Shen DY, Tian L, Zhang QY, Liao LX and Chen QX: Apoptosis induced by aqueous extracts of crocodile bile in human heptacarcinoma SMMC-7721. Appl Biochem Biotechnol 170: 15-24, 2013.

11. Wu ZH, Lu MK, Hu LY and Li X: Praziquantel synergistically enhances paclitaxel efficacy to inhibit cancer cell growth. Plos One 7: e51721, 2012.

12. Resnitzky D and Reed SI: Different roles for cyclins D1 and E in regulation of the G1-to-S transition. Mol Cell Biol 15: 3463-3469, 1995.

13. Lo AC, Woo TT, Wong RL and Wong D: Apoptosis and other cell death mechanisms after retinal detachment: Implications for photoreceptor rescue. Ophthalmologica 226 (Suppl 1): S10-S17, 2011.

14. Ozben T: Oxidative stress and apoptosis: Impact on cancer therapy. J Pharm Sci 96: 2181-2196, 2007.

15. Waldbaum S and Patel M: Mitochondrial dysfunction and oxidative stress: A contributing link to acquired epilepsy? J Bioenerg Biomembr 42: 449-455, 2010.

16. Blattner JR, He L and Lemasters JJ: Screening assays for the mitochondrial permeability transition using a fluorescence multiwell plate reader. Anal Biochem 295: 220-226, 2001

17. Kroemer G, Dallaporta B and Resche-Rigon M: The mitochondrial death/life regulator in apoptosis and necrosis. Annu Rev Physiol 60: 619-642, 1998

18. Graham MV, Purdy JA, Emami B, Harms W, Bosch W, Lockett MA and Perez CA: Clinical dose-volume histogram analysis for pneumonitis after 3D treatment for non-small cell lung cancer (NSCLC). Int J Radiat Oncol Biol Phys 45: 323-329, 1999.

19. Mork CN, Faller DV and Spanjaard RA: A mechanistic approach to anticancer therapy: Targeting the cell cycle with histone deacetylase inhibitors. Curr Pharm Des 11: 1091-1104, 2005.

20. Ohtsubo M, Theodoras AM, Schumacher J, Roberts JM and Pagano M: Human cyclin E, a nuclear protein essential for the G1-to-S phase transition. Mol Cell Biol 15: 2612-2624, 1995.

21. Chow KU, Nowak D, Boehrer S, Ruthardt M, Knau A, Hoelzer D, Mitrou PS and Weidmann E: Synergistic effects of chemotherapeutic drugs in lymphoma cells are associated with down-regulation of inhibitor of apoptosis proteins (IAPs), prostate-apoptosis-response-gene 4 (Par-4), death-associated protein (Daxx) and with enforced caspase activation. Biochem Pharmacol 66: 711-724, 2003.
22. Hunot S and Flavell RA: Apoptosis. Death of a monopoly? Science 292: 865-866, 2001.

23. Danial NN and Korsmeyer SJ: Cell death: Critical control points. Cell 116: 205-219, 2004.

24. Devasagayam TP, Tilak JC, Boloor KK, Sane KS, Ghaskadbi SS and Lele RD: Free radicals and antioxidants in human health: Current status and future prospects. J Assoc Physicians India 52: 794-804, 2004

25. Mannella CA: Structure and dynamics of the mitochondrial inner membrane cristae. Biochim Biophys Acta 1763: 542-548, 2006.

26. Weinberg F and Chandel NS: Mitochondrial metabolism and cancer. Ann N Y Acad Sci 1177: 66-73, 2009.

27. Mohan S, Abdul AB, Abdelwahab SI, Al-Zubairi AS, Sukari MA, Abdullah R, Elhassan Taha MM, Ibrahim MY and Syam S: Typhonium flagelliforme induces apoptosis in CEMss cells via activation of caspase-9, PARP cleavage and cytochrome c release: Its activation coupled with $\mathrm{G} 0 / \mathrm{G} 1$ phase cell cycle arrest. J Ethnopharmacol 131: 592-600, 2010.

28. Estaquier J, Vallette F, Vayssiere JL and Mignotte B: The mitochondrial pathways of apoptosis. Adv Exp Med Biol 942: 157-183, 2012.

29. Brenner C and Kroemer G: Apoptosis. Mitochondria-the death signal integrators. Science 289: 1150-1151, 2000.

30. Dejean LM, Martinez-Caballero S and Kinnally KW: Is MAC the knife that cuts cytochrome $\mathrm{c}$ from mitochondria during apoptosis? Cell Death Differ 13: 1387-1395, 2006.

31. Martindale JL and Holbrook NJ: Cellular response to oxidative stress: Signaling for suicide and survival. J Cell Physiol 192: $1-15,2002$.

32. Cecconi F, Alvarez-Bolado G, Meyer BI, Roth KA and Gruss P: Apaf1 (CED-4 homolog) regulates programmed cell death in mammalian development. Cell 94: 727-737, 1998.

33. Pan G, O'Rourke K and Dixit VM: Caspase-9, Bcl-XL, and Apaf-1 form a ternary complex. J Biol Chem 273: 5841-5845, 1998.

34. Pop C, Timmer J, Sperandio S and Salvesen GS: The apoptosome activates caspase-9 by dimerization. Mol Cell 22: 269-275, 2006

35. Sah NK, Khan Z, Khan GJ and Bisen PS: Structural, functional and therapeutic biology of survivin. Cancer lett 244: 164-171, 2006. 